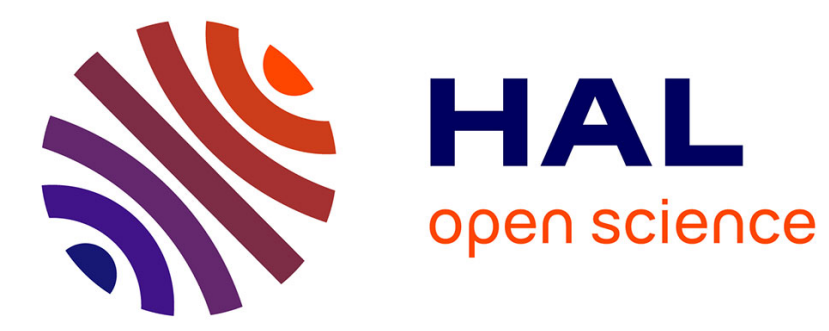

\title{
Two multiplexed sets of 21 and 18 microsatellites for Phoxinus phoxinus (L.) and Gobio gobio (L.) developed by cross-species amplification
}

Rémi Grenier, Caroline Costedoat, Rémi Chappaz, Vincent Dubut

\section{- To cite this version:}

Rémi Grenier, Caroline Costedoat, Rémi Chappaz, Vincent Dubut. Two multiplexed sets of 21 and 18 microsatellites for Phoxinus phoxinus (L.) and Gobio gobio (L.) developed by cross-species amplification. European Journal of Wildlife Research, 2013, 59 (2), pp.291-297. 10.1007/s10344-013-0693-z . hal-01933451

\section{HAL Id: hal-01933451 \\ https://hal.science/hal-01933451}

Submitted on 23 Nov 2018

HAL is a multi-disciplinary open access archive for the deposit and dissemination of scientific research documents, whether they are published or not. The documents may come from teaching and research institutions in France or abroad, or from public or private research centers.
L'archive ouverte pluridisciplinaire HAL, est destinée au dépôt et à la diffusion de documents scientifiques de niveau recherche, publiés ou non, émanant des établissements d'enseignement et de recherche français ou étrangers, des laboratoires publics ou privés. 


\title{
Two multiplexed sets of 21 and 18 microsatellites for Phoxinus phoxinus (L.) and Gobio gobio (L.) developed by cross-species amplification
}

\author{
Rémi Grenier • Caroline Costedoat • Rémi Chappaz • \\ Vincent Dubut
}

\begin{abstract}
A total of 68 cyprinid microsatellites were screened for cross-species amplification in order to develop three PCR multiplex kits for the Eurasian minnow (Phoxinus phoxinus L.) and the gudgeon (Gobio gobio L.). The multiplex kits cluster 21 and 18 microsatellites for P. phoxinus and G. gobio, respectively. All loci were evaluated using $\sim 80$ individuals sampled from three distinct populations. By multiplexing the markers, we aim to decrease genotyping costs and increase time efficiency. These two microsatellite sets represent a valuable tool for ecological, evolutionary, conservation and management issues.
\end{abstract}

Keywords Microsatellite - Cyprinid P Population genetics · Conservation $\cdot$ Management

\section{Introduction}

The Eurasian minnow (Phoxinus phoxinus L. 1758) and the gudgeon (Gobio gobio L. 1758) are both widespread and common freshwater cyprinid species in Europe. They are commonly stocked and are used by anglers as fry, bait or forage species (Kottelat and Freyhof 2007). Phoxinus

Communicated by P. C. Alves

R. Grenier $\cdot$ C. Costedoat $\cdot$ R. Chappaz $\cdot$ V. Dubut $(\bowtie)$

Aix Marseille Université, CNRS, IRD, IMBE-UMR 7263, Equipe

Evolution Génome Environnement, Centre Saint-Charles,

Case 36, 3 place Victor Hugo,

13331 Marseille Cedex 3, France

e-mail: vincent.dubut@imbe.fr

V. Dubut

CNRS, SEEM-USR 2936, Station d'Ecologie Expérimenale,

2 route du CNRS,

09200 Moulis, France phoxinus and G. gobio are therefore prone to recurrent translocation and are considered as invasive species in some European areas where they are not native (Crivelli 1995; Elvira and Alomodóvar 2001; Hesthagen and Sanlund 2007; Museth et al. 2007). In their native range however, they proved to be valuable models either for studying the impact of water pollution on freshwater fishes (Knapen et al. 2009) or for investigating the processes involved in local adaptive variation (Collin and Fumagalli 2011). Furthermore, it was shown that anthropogenic habitat fragmentation impacts the genetic diversity and structure of these two species differently (Blanchet et al. 2010). Together, P. phoxinus and G. gobio thus represent a valuable system for an array of management, conservation and evolutionary purposes. Additionally, molecular and morphological studies recently suggested revisions of the taxonomy of both P. phoxinus and G. gobio (Kottelat and Persat 2005; Kottelat 2007; Mendel et al. 2008), implying critical conservation and management issues.

To date, no specific microsatellites have been developed for $P$. phoxinus and only a limited set of markers is available for G. gobio (six reliable markers; Knapen et al. 2006, 2009). The development of additional markers would permit the evolutionary history of these species to be deciphered and would allow a straightforward evaluation of the genetic diversity and structure in both evolutionary ecology and conservation frameworks. From this perspective, crossspecies amplification represents a cost- and time-effective approach (e.g. Wang et al. 2009; Rosenbom et al. 2012) and has proven especially valuable for cyprinid species (Hamilton and Tyler 2008; Dubut et al. 2010). Crossspecies amplification was previously used for $P$. phoxinus and G. gobio in order to identify amplifiable and polymorphic microsatellites (Holmen et al. 2005, 2009). Nevertheless, the screening was conducted on a limited 
number of individuals for most of the markers, which prevented full validation and characterisation. Using crossspecies amplification, our study aimed to (1) identify a sufficient number of loci that would allow for discriminating populations at a microgeographic scale (see Nikolic et al. 2009), (2) standardise PCR conditions (one single PCR protocol) and (3) multiplex loci in order to minimise the genotyping time and cost.

\section{Materials and methods}

Fish were caught by electrofishing, and caudal fin samples were collected before the fish were returned to their original sampling site. Two distinct locations from the Rhone River system (Isere River and Saone River, Eastern France) and one location from the Meuse River (Northern France) were sampled. At each location, 25 to 33 individuals of P. phoxinus and G. gobio were collected (see Table 1). Additional samples were collected in the Garonne and Loire River systems (France) for preliminary amplifiability and polymorphism testing. DNA was extracted from $\sim 0.25 \mathrm{~cm}^{2}$ of fin using the Gentra ${ }^{\circledR}$ Puregene ${ }^{\mathrm{TM}}$ Tissue Kit (QIAGEN).

To identify amplifiable loci, 56 published primer sets developed for Cyprinidae species were tested: BL1-2b, BL1-30, BL1-36, BL1-44, BL1-61, BL1-84, BL1-98, BL1-153, BL1158, BL1-T2 and BL2-114 (Dubut et al. 2009a, 2012); Ca1 and Ca3 (Dimsoski et al. 2000); CnaB-030, CnaD-112, CnaF177, CtoA-254, CtoE-249, CtoF-172, CtoG-075 and CtoG216 (Dubut et al. 2010); CypG9, CypG24 and CypG30 (Baerwald and May 2004); IV04 (Salgueiro et al. 2003); LC27 (Vyskočilová et al. 2007); LceC1 and LceA149 (Larno et al. 2005); LleA-029, LleA-071, LleA-131, LleA150, LleA-191, LleB-048, LleB-071, LleB-072, LleC-049, LleC-090 and LleC-184 (Dubut et al. 2009b, 2010); Lco1, Lco3 and Lco5 (Turner et al. 2004); Lid8 and Rru4 (Barinova et al. 2004); Lsou5, Lsou8, Lsou10, Lsou19, Lsou29 and Lsou34 (Muenzel et al. 2007); MFW1 (Crooijmans et al. 1997); N7K4 (Mesquita et al. 2003); Ppro132 (Bessert and Ortí 2003); Rhca20 (Girard and Angers 2006); Rser10 (Dawson et al. 2003); and Z21908 (Shimoda et al. 1999). These primer pairs were initially tested for amplification using four individuals, stemming from Garonne, Loire, Meuse and Rhone drainages (France). Thermocycling was performed using one single protocol: $95^{\circ} \mathrm{C}$ for $15 \mathrm{~min}$, followed by 30 cycles $\left(94{ }^{\circ} \mathrm{C}\right.$ for $30 \mathrm{~s}, 56^{\circ} \mathrm{C}$ for $90 \mathrm{~s}, 72{ }^{\circ} \mathrm{C}$ for $\left.60 \mathrm{~s}\right)$ and $60^{\circ} \mathrm{C}$ for $45 \mathrm{~min}$. PCR were conducted in a total volume of $10 \mu \mathrm{L}$ containing $\sim 20$ ng of DNA and using the QIAGEN Multiplex PCR Kit (QIAGEN). Visualisation of the amplicons was performed by electrophoresis on $1.5 \%$ agarose gels. We retained loci that amplified in all individuals and that gave clean PCR products, i.e. discrete single bands or at most two bands when a large size difference between alleles existed.
The selected loci were then amplified using forward primers labelled with fluorescent dye 6-FAM (Eurogentec), PET, NED or VIC (Applied Biosystems) with PCR conditions as described above and using eight individuals (two individuals from each of the Garonne, Loire, Meuse and Rhone River systems). Visualisation of the amplicons was conducted on an ABI 3130xl Genetic Analyzer (Applied Biosystems). Allele sizes were scored against an internal GeneScan-500 LIZ ${ }^{\circledR}$ Size Standard (Applied Biosystems) and genotypes were obtained using GeneMapper ${ }^{\circledR} 3.7$ (Applied Biosystems). We retained loci that (1) amplified in all individuals, (2) had unambiguous genotype profiles and (3) were polymorphic.

At this stage, 22 loci were retained for $P$. phoxinus. However, only 10 loci were selected for G. gobio. Therefore, 12 additional primers pairs for loci previously detected as polymorphic for G. gobio (Holmen et al. 2005; Vyskočilová et al. 2007; Hamilton and Tyler 2008) were tested: Ca13 and Ca14 (Dimsoski et al. 2000); LC293 (Vyskočilová et al. 2007); Lco4 (Turner et al. 2004); Lid1 (Barinova et al. 2004); and Z1206, Z6804, Z8249, Z10362, Z11841, Z14008 and Z15401 (Shimoda et al. 1999). These 12 markers were tested on G. gobio, permitting the selection of three additional loci using the protocols and criteria described above. Furthermore, five specific microsatellites (Gob12, Gob15, Gob16, Gob22, Gob28; Knapen et al. 2006) were included, resulting in a total of 18 polymorphic loci for $G$. gobio. Finally, the primer pairs selected for P. phoxinus and $G$. gobio were combined into three PCR multiplex kits for each species (Table 1).

The microsatellites were evaluated using three distinct populations of P. phoxinus and G. gobio (Table 1). GENEPOP 4.0 (Rousset 2008) was used to (1) test HardyWeinberg (HW) equilibrium, (2) estimate the observed $\left(H_{\mathrm{o}}\right)$ and expected $\left(H_{\mathrm{e}}\right)$ heterozygosities for all loci and populations and (3) test for linkage disequilibrium (LD) among loci within populations. MICRO-CHECKER 2.2.3 (van Oosterhout et al. 2004) was used to analyse the causes of departures from HW equilibrium. In order to graphically prospect the discrimination power of the two sets of markers at population scale, factorial correspondence analyses (FCA) were conducted on genotypes using GENETIX 4.05 (Belkhir et al. 2004) (Fig. 1). For FCA, the locus Ca3 was discarded from the $P$. phoxinus dataset since null alleles were detected in all three populations (see below).

\section{Results and discussion}

Based on three population samples, the total number of alleles ranged from 3 to 42 for $P$. phoxinus (excluding locus Ca3) and from 2 to 33 for G. gobio, and the expected heterozygosity of polymorphic loci ranged from 0.04 to 0.95 for P. phoxinus and from 0.09 to 0.90 for G. gobio 


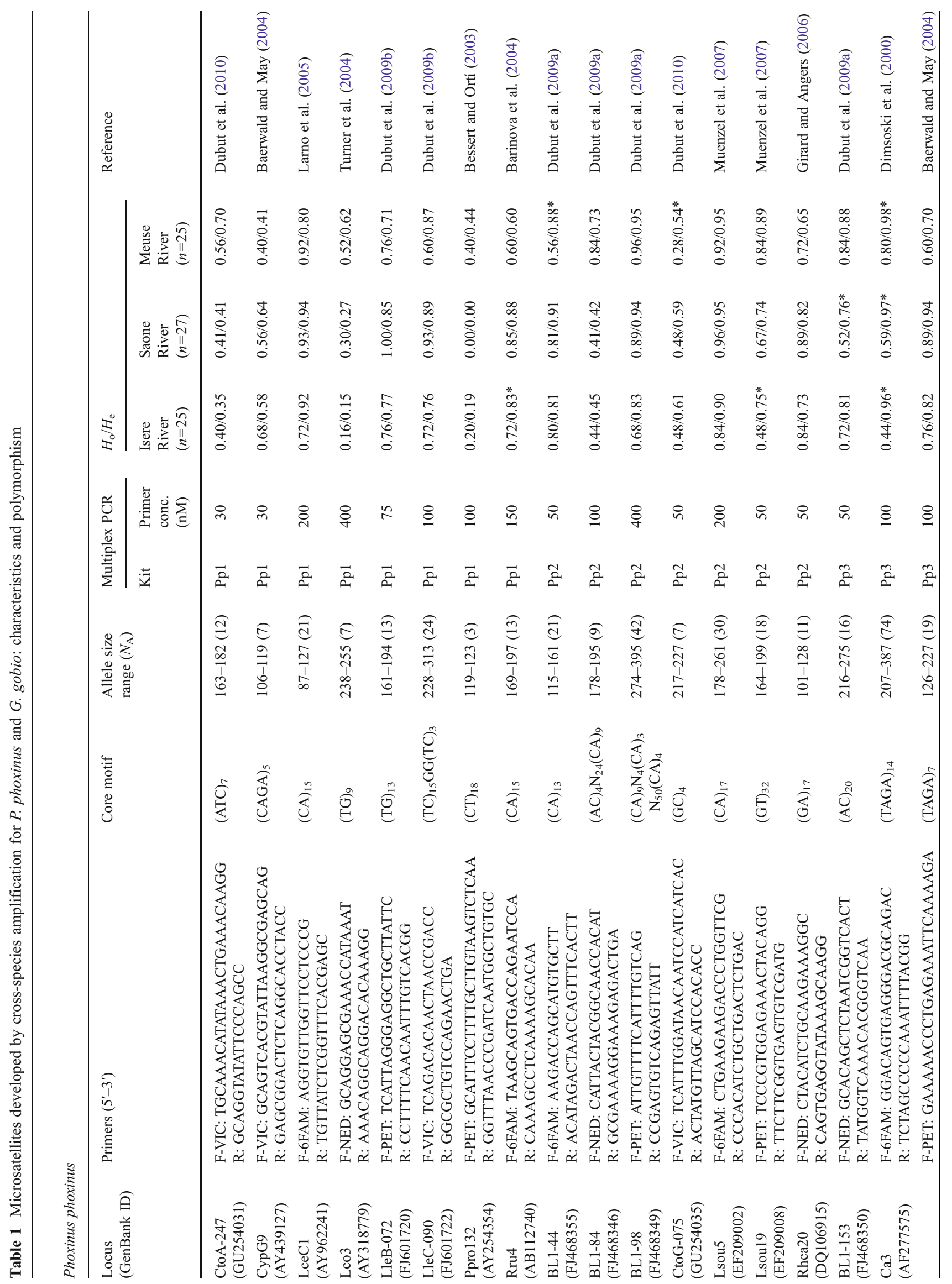




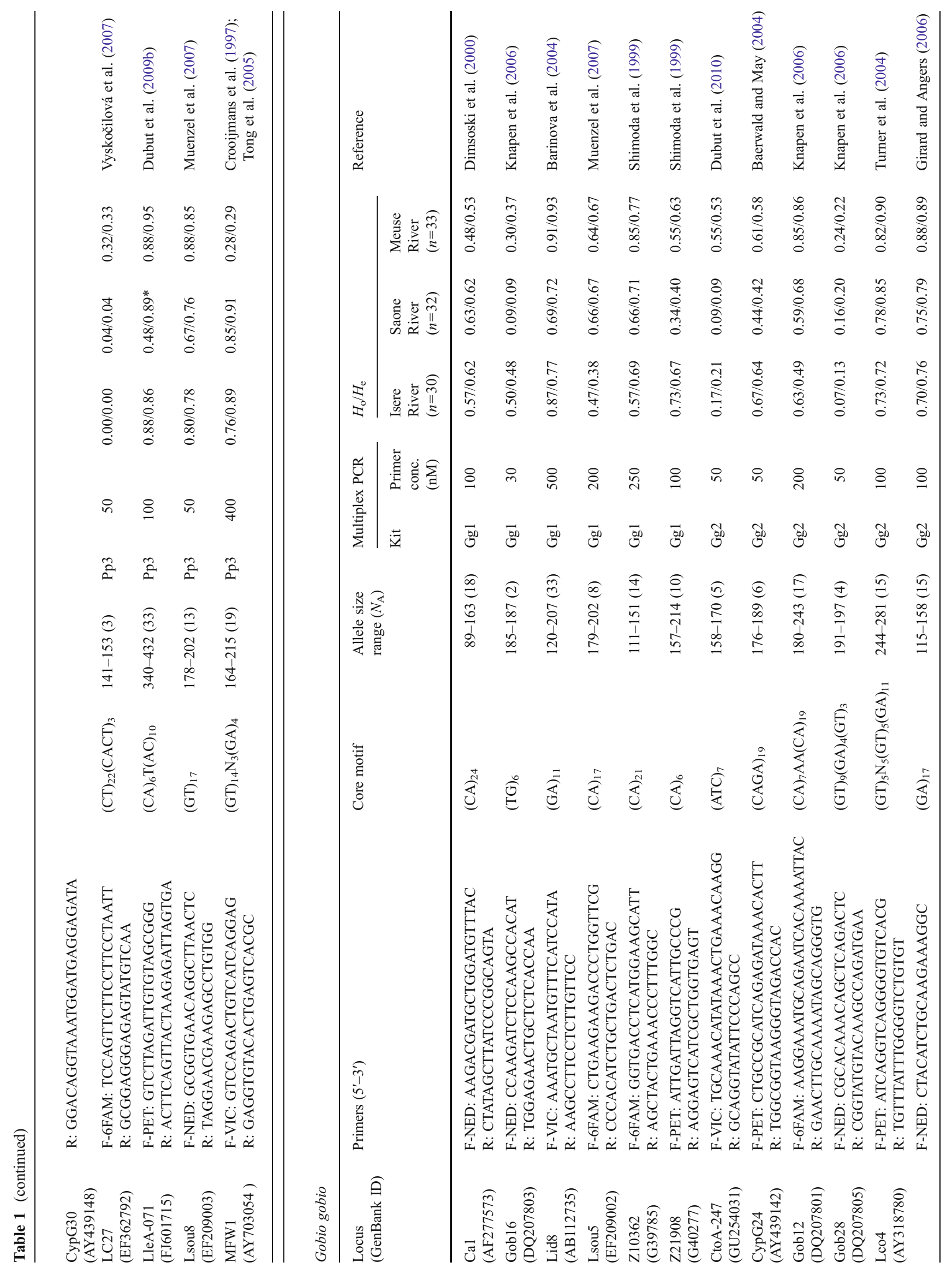



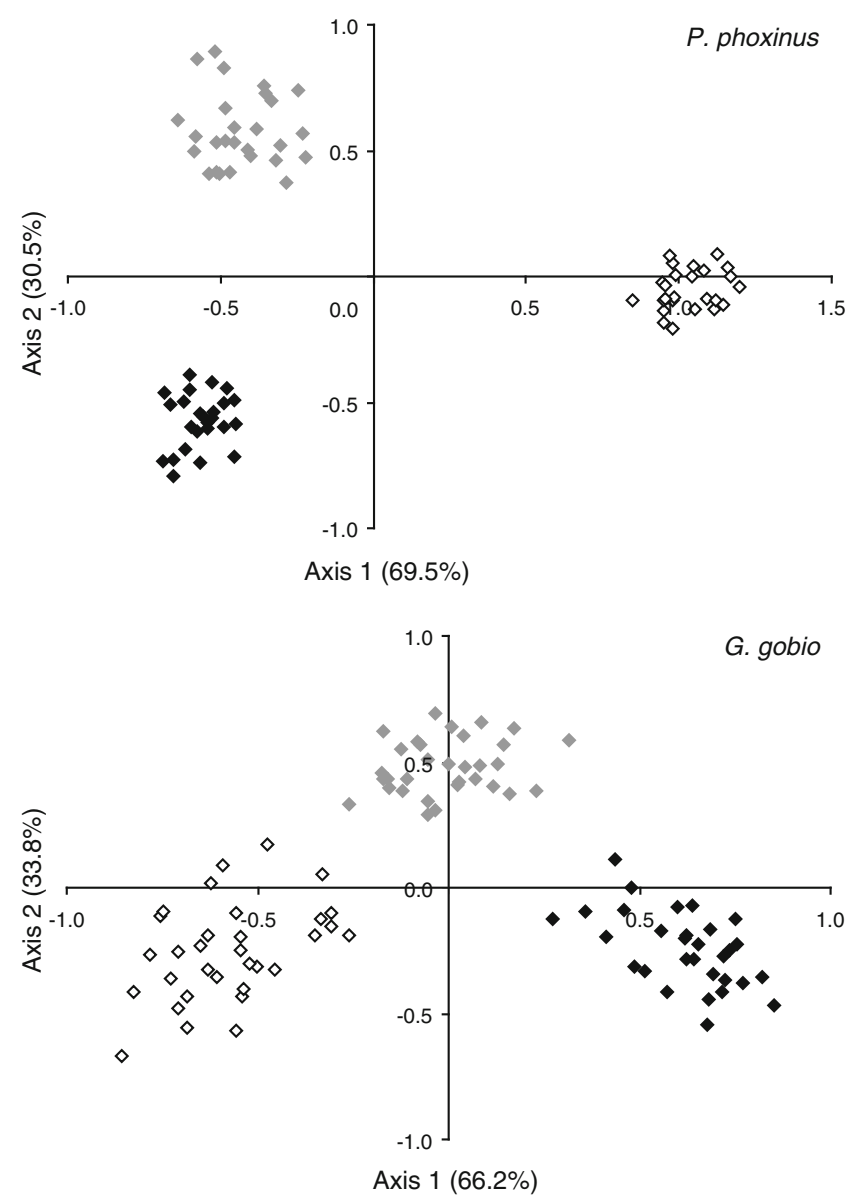

- Isere River (Rhone drainage) $\quad$ Saone River (Rhone drainage)

$\diamond$ Meuse River (Meuse drainage)

Fig. 1 Factorial correspondence analyses (FCA) of microsatellite genotypes of three populations of P. phoxinus (21 loci) and G. gobio (18 loci)

(Table 1). For G. gobio, LC293 was monomorphic in the three population samples, although polymorphic (including heterozygotes) in the eight individual samples used for the preliminary tests. After applying the false discovery rate (FDR) controlling procedure (Benjamini and Hochberg 1995), no significant HW disequilibrium was detected for G. gobio. On the contrary, significant HW disequilibrium was detected for P. phoxinus in one out of three populations: loci BL1-44 (Meuse population), BL1-153 (Saone), CtoG075 (Meuse), LleA-071 (Saone), Lsou19 (Isere) and Rru4 (Isere). Additionally, $\mathrm{Ca} 3$ exhibits $\mathrm{HW}$ disequilibrium in all three $P$. phoxinus populations (Table 1). For loci at HW disequilibrium, MICRO-CHECKER detected neither evidence for scoring error due to stuttering nor evidence for large allele dropout. However, null alleles may be present at all loci (which present heterozygotes deficiency), except BL1153 and Rru4. After FDR correction, no LD was detected in P. phoxinus. In G. gobio, Lco4 and CypG24 showed significant LD in the Isere River population only, likely indicating a local demographic event or local selection. 
Furthermore, using 18 microsatellites and 21 microsatellites, FCA permitted the unambiguous discrimination of the populations of G. gobio and P. phoxinus, respectively. Although some population samples were collected from the same drainage, any overlap was observed between the distinct populations (Fig. 1).

Using cross-species amplification and five specific markers, we were able to develop 18 microsatellites for $G$. gobio and 21 microsatellites (excluding Ca3) for P. phoxinus. To catch the widest allelic range and to minimise the retention of loci with null alleles, individuals from four different hydrographical systems (Garonne, Loire, Rhone and Meuse Rivers) were included in the microsatellite development protocol (see Sinama et al. 2011). For P. phoxinus however, punctual occurrences of null alleles were detected at loci BL1-44, CtoG-075, LleA-071 and Lsou19. This suggests that these four loci must be used with caution and should be further evaluated depending on the geographic location of samples and the objectives of the study.

Finally, standardising the PCR protocol and multiplexing the microsatellite loci make their use more time- and costeffective and minimise errors during the compilation of genotypes (see Guichoux et al. 2011). Both sets of loci also proved to correctly discriminate populations. These two sets of microsatellites therefore represent a useful tool for an array of ecological, evolutionary, conservation and management applications. For instance, these markers could be useful in developing molecular tools for relatedness and parentage analyses (as initiated by Bernhardt et al. 2012).

Acknowledgments Data used in this work were partly produced through molecular genetic analysis technical facilities of the Plateforme Génomique Environnementale of LabEx CeMEB (Montpellier, France). We are very grateful to the technicians from the Office National de l'Eau et des Milieux Aquatiques (ONEMA, France) for their very valuable help with sample collection. This work was supported by the ONEMA (project NeoTaxon).

\section{References}

Baerwald MR, May B (2004) Characterization of microsatellite loci for five members of the minnow family Cyprinidae found in the Sacramento-San Joaquim Delta and its tributaries. Mol Ecol Notes 4:385-390

Barinova A, Yadrenkina E, Nakajima M, Taniguchi N (2004) Identification and characterization of microsatellite DNA markers developed in ide Leuciscus idus and Siberian roach Rutilus rutilus. Mol Ecol Notes 4:86-88

Belkhir K, Borsa P, Chikhi L, Raufaste N, Bonhomme F (2004) GENETIX 4.05: logiciel sous Windows TM pour la génétique des populations, Laboratoire Génome Populations Interactions (UMR 5000, CNRS, Université de Montpellier II), Montpellier. http:// kimura.univ-montp2.fr/genetix/
Benjamini Y, Hochberg Y (1995) Controlling the false discovery rate: a practical and powerful approach to multiple testing. J R Stat Soc Ser B Stat Methodol 57:289-300

Bernhardt B, Lampert KP, Leese F, Mayer C, Tollrian R (2012) Are shoals of minnow Phoxinus phoxinus formed by close kin? J Fish Biol 80:713-721

Bessert ML, Ortí G (2003) Microsatellite loci for paternity analysis in the fathead minnow, Pimephales promelas (Teleostei: Cyprinidae). Mol Ecol Notes 3:532-534

Blanchet S, Rey O, Etienne R, Lek S, Loot G (2010) Species-specific responses to landscape fragmentation: implications for management strategies. Evol Appl 3:291-304

Collin H, Fumagalli L (2011) Evidence for morphological and adaptive genetic divergence between lake and stream habitats in European minnows (Phoxinus phoxinus, Cyprinidae). Mol Ecol 20:4490-4502

Crivelli AJ (1995) Are fish introductions a threat to endemic freshwater fishes in the northern Mediterranean region? Biol Conserv 72:311-319

Crooijmans RPMA, Bierbooms VAF, Komen J, Van der Poel JJ, Groenen MAM (1997) Microsatellite markers in common carp (Cyprinus carpio L.). Anim Genet 28:129-134

Dawson DA, Burland TM, Douglas A, Le Comber SC, Bradshaw M (2003) Isolation of microsatellite loci in the freshwater fish, the bitterling Rhodeus sericeus (Teleostei: Cyprinidae). Mol Ecol Notes 3:199-202

Dimsoski P, Toth GP, Bagley MJ (2000) Microsatellite characterization in central stoneroller Campostoma anomalum (Pisces: Cyprinidae). Mol Ecol 9:2187-2189

Dubut V, Martin JF, Costedoat C, Chappaz R, Gilles A (2009a) Isolation and characterization of polymorphic microsatellite loci in the freshwater fishes Telestes souffia and Telestes muticellus (Teleostei: Cyprinidae). Mol Ecol Resour 9:1001-1005

Dubut V, Martin JF, Gilles A, van Houdt J, Chappaz R, Costedoat C (2009b) Isolation and characterization of polymorphic microsatellite loci for the dace complex: Leuciscus leuciscus (Teleostei: Cyprinidae). Mol Ecol Resour 9:1179-1183

Dubut V, Sinama M, Martin JF, Meglécz E, Fernandez J, Chappaz R, Gilles A, Costedoat C (2010) Cross-species amplification of 41 microsatellites in European cyprinids: a tool for evolutionary, population genetics and hybridization studies. BMC Res Notes 3:135

Dubut V, Fouquet A, Voisin A, Costedoat C, Chappaz R, Gilles A (2012) From late Miocene to Holocene: processes of differentiation within the Telestes genus (Actinopterygii: Cyprinidae). PLoS One 7:e34423

Elvira B, Alomodóvar A (2001) Freshwater fish introductions in Spain: facts and figures at the beginning of the 21 st century. J Fish Biol 59:323-331

Girard P, Angers B (2006) Characterization of microsatellite loci in longnose dace (Rhinichthys cataractae) and interspecific amplification in five other Leuciscinae species. Mol Ecol Notes 6:69-71

Guichoux E, Lagache L, Wagner S, Chaumeil P, Léger P, Lepais O, Lepoittevin C, Malausa T, Revardel E, Salin F, Petit RJ (2011) Current trends in microsatellite genotyping. Mol Ecol Resour 11:591-611

Hamilton PB, Tyler CR (2008) Identification of microsatellite loci for parentage analysis in roach Rutilus rutilus and eight other cyprinid fish by cross-species amplification, and a novel test for detecting hybrids between roach and other cyprinids. Mol Ecol Resour 8:462-465

Hesthagen T, Sanlund OT (2007) Non-native freshwater fishes in Norway: history, consequences and perspectives. J Fish Biol 71:173-183

Holmen J, Vøllestad LA, Jakobsen KS, Primmer CR (2005) Crossspecies amplification of zebrafish and central stoneroller microsatellite loci in six other cyprinids. J Fish Biol 66:851-859 
Holmen J, Vøllestad LA, Jakobsen KS, Primmer CR (2009) Crossspecies amplification of 36 cyprinid microsatellite loci in Phoxinus phoxinus (L.) and Scardinius erythrophthalmus (L.). BMC Res Notes 2:248

Knapen D, Taylor M, Blust R, Verheyen E (2006) Isolation and characterization of polymorphic microsatellite loci in the gudgeon, Gobio gobio (Cyprinidae). Mol Ecol Notes 6: 387-389

Knapen D, DeWolf H, Knaepkens G, Bervoets L, Eensb M, Blust R, Verheyen E (2009) Historical metal pollution in natural gudgeon populations: inferences from allozyme, microsatellite and condition factor analysis. Aquat Toxicol 95:17-26

Kottelat M (2007) Three new species of Phoxinus from Greece and southern France (Teleostei: Cyprinidae). Ichthyol Explor Freshw 18:145-162

Kottelat M, Freyhof J (2007) Handbook of European freshwater fishes. Publication Kottelat, Cornol

Kottelat M, Persat H (2005) The genus Gobio in France, with redescription of G. gobio and description of two new species (Teleostei: Cyprinidae). Cybium 29:211-234

Larno V, Launey S, Devaux A, Laroche J (2005) Isolation and characterization of microsatellite loci from chub Leuciscus cephalus (Pisces: Cyprinidae). Mol Ecol Notes 5:752-754

Mendel J, Lusk S, Vasil'eva ED, Vasil'ev VP, Lusková V, Ekmekci FG, Erk'akan F, Ruchin A, Koščo J, Vetešník L, Halačka K, Šanda R, Pashkov AN, Reshetnikov SI (2008) Molecular phylogeny of the genus Gobio Cuvier, 1816 (Teleostei: Cyprinidae) and its contribution to taxonomy. Mol Phylogenet Evol 47:1061-1075

Mesquita N, Cunha C, Hänfling B, Carvalho GR, Zé-Zé L, Tenreiro R, Coelho MM (2003) Isolation and characterization of polymorphic microsatellite loci in the endangered Portuguese freshwater Squalius aradensis (Cyprinidae). Mol Ecol Notes 3: $572-574$

Muenzel FM, Sanetra M, Salzburger W, Meyer A (2007) Microsatellites from the vairone Leuciscus souffia (Pisces: Cyprinidae) and their application to closely related species. Mol Ecol Notes 7:1048-1050

Museth J, Hesthagen T, Sandlund OT, Thorstad EB, Ugedal O (2007) The history of the minnow Phoxinus phoxinus (L.) in Norway: from harmless species to pest. J Fish Biol 71:184-195
Nikolic N, Fève K, Chevalet C, Høyheim B, Riquet J (2009) A set of 37 microsatellite DNA markers for genetic diversity and structure analysis of Atlantic salmon Salmo salar populations. J Fish Biol 74:458-466

Rosenbom S, Costa V, Steck B, Moehlman P, Beja-Pereira A (2012) Cross-species genetic markers: a useful tool to study the world's most threatened wild equid-Equus africanus. Eur J Wildl Res 58:609-613

Rousset F (2008) GENEPOP'007: a complete reimplementation of the GENEPOP software for Windows and Linux. Mol Ecol Resour 8:103-106

Salgueiro P, Carvalho G, Collares-Pereira MJ, Coelho MM (2003) Microsatellite analysis of genetic population structure of the endangered cyprinid Anaecypris hispanica in Portugal: implications for conservation. Biol Conserv 109:47-56

Shimoda N, Knapik EW, Ziniti J, Sim C, Yamada E, Kaplan S, Jackson D, de Sauvage F, Jacob H, Fishman MC (1999) Zebrafish genetic map with 2000 microsatellite markers. Genomics 58:219-232

Sinama M, Dubut V, Costedoat C, Gilles A, Junker J, Malausa T, Martin JF, Nève G, Pech N, Schmitt T, Zimmermann M, Meglécz E (2011) Challenges of microsatellite development in Lepidoptera: Euphydryas aurinia (Nymphalidae) as a case study. Eur J Entomol 108:261-266

Tong J, Yu X, Liao X (2005) Characterization of a highly conserved microsatellite marker with utility potentials in cyprinid fishes. $\mathrm{J}$ Appl Ichthyol 21:232-235

Turner TF, Dowling TE, Broughton RE, Gold JR (2004) Variable microsatellite markers amplify across divergent lineages of cyprinid fishes (subfamily Leuciscinae). Conserv Genet 5:279-281

van Oosterhout C, Hutchinson WF, Wills DP, Shipley P (2004) MICROCHECKER: software for identifying and correcting genotyping errors in microsatellite data. Mol Ecol Notes 4:535-538

Vyskočilová M, Šimková A, Martin JF (2007) Isolation and characterization of microsatellites in Leuciscus cephalus (Cypriniformes, Cyprinidae) and cross-species amplification within the family Cyprinidae. Mol Ecol Notes 7:1150-1154

Wang N, Chang J, Gu LY, Zang ZW (2009) Polymorphic microsatellites in the Reeves's pheasant developed by cross-species amplification. Eur J Wildl Res 55:627-629 